\title{
Use of serious games in medicine: a literature revision
}

\author{
Uso de jogos sérios na medicina: uma revisão dla literatura \\ Uso de juegos serios en medicina: una revisión de literatura
}

Received: 12/01/2021 | Reviewed: 12/07/2021 | Accept: 12/08/2021| Published: 12/16/2021

\author{
Francisco Anderson Mariano da Silva \\ ORCID: https://orcid.org/0000-0001-9797-7552 \\ Universidade Federal de São Paulo, Brasil \\ E-mail: francisco.anderson@unifesp.br \\ Tiago Silva da Silva \\ ORCID: https://orcid.org/0000-0001-8459-7833 \\ Universidade Federal de São Paulo, Brasil \\ E-mail: silva.tiago@unifesp.br \\ Ezequiel Roberto Zorzal \\ ORCID: https://orcid.org/0000-0002-0938-7374 \\ Universidade Federal de São Paulo, Brasil \\ E-mail: ezorzal@unifesp.br
}

\begin{abstract}
It is noticeable that more and more medical professionals have been searching for strategies to keep people engaged both in the recovery processes (cognitive or physical) and in the teaching part. It is possible to observe that the insertion of Serious Games has been offering this innovative possibility, which allows the development of new possibilities for several areas of knowledge. This study aims to carry out a review on the use of Serious Games in Medicine, exploring how the method has been used. The methodology used was a systematic review. Articles published from 2015 to 2020 in indexed in three databases such as IEEE, Scopus, Scielo, among others, were searched. If used correctly, the Serious Games can help in the rehabilitation process of patients affected by some sequelae caused by stroke (CVA - Cerebral Vascular Accident), and also in the rehabilitation process of people with degenerative problems. It was also possible to observe that SG can be used as motivating and engaging tools for medical students.
\end{abstract}

Keywords: Serious games; Medicine; Systematica Review.

\section{Resumo}

Nota-se que cada vez mais profissionais médicos buscam estratégias para manter as pessoas envolvidas tanto nos processos de recuperação (cognitiva ou física) quanto na parte pedagógica. Percebe-se que a inserção dos Serious Games (SG) tem oferecido essa possibilidade inovadora, que permite o desenvolvimento de novas possibilidades para diversas áreas do conhecimento. Este estudo tem como objetivo realizar uma revisão sobre a utilização da GE na Medicina, explorando como o método tem sido utilizado. A metodologia utilizada foi uma revisão sistemática. Artigos publicados de 2015 a 2020 foram pesquisados em bases de dados indexadas como IEEE, Scopus, Scielo, entre outras. Se usado corretamente, o GS pode auxiliar no processo de reabilitação de pacientes acometidos por alguma sequela do AVC (AVC - Acidente Vascular Cerebral), e também no processo de reabilitação de pessoas com problemas degenerativos. Também foi possível observar que o GE pode ser utilizado como uma ferramenta motivadora e atrativa para estudantes de medicina.

Palavras-chave: Serious games; Medicina; Revisão Sistematica.

\section{Resumen}

Se nota que cada vez son más los profesionales médicos que buscan estrategias para mantener a las personas involucradas tanto en los procesos de recuperación (cognitiva o física) como en la parte docente. Se puede observar que la inserción de Serious Games (SG) viene ofreciendo esta posibilidad innovadora, que permite el desarrollo de nuevas posibilidades para varias áreas del conocimiento. Este estudio tiene como objetivo realizar una revisión sobre el uso de SG en Medicina, explorando cómo se ha utilizado el método. La metodología utilizada fue una revisión sistemática. Se buscaron artículos publicados de 2015 a 2020 en bases de datos indexadas como IEEE, Scopus, Scielo, entre otras. Si se utiliza correctamente, el SG puede ayudar en el proceso de rehabilitación de pacientes afectados por algunas secuelas provocadas por ictus (ACV - Accidente Vascular Cerebral), y también en el proceso de rehabilitación de personas con problemas degenerativos. También fue posible observar que la SG se puede utilizar como herramienta motivadora y atractiva para los estudiantes de medicina.

Palabras clave: Juegos serios; Medicamento; Revision Sistemátca. 


\section{Introduction}

With the advancement of technology, tools have been optimized over time to improve processes (Gomes et al., 2018). Clinical decision making is a complex challenge for physicians and medical students; moreover, how to apply the knowledge they have learned to arrive at a patient's diagnosis is also a challenging learning process (Schmidt; Grigull, 2018). Serious Games have been used for various educational interventions in health promotion and prevention (Tolks et al., 2018).

There are numerous teaching methods that can go beyond traditionalism. These methods have information that facilitates communication and learning and can be extensively changed. In many cases these changes are absolutely necessary for the achievement of certain goals (Silva \& Morais, 2011).

According to Rocha, Bittencourt and Isotani (2015), a Serious Game (SG) is a software with a graphical interface with information and possible interactions, however, it must have primary characteristics that ensure the efficiency of the SG, such as rules, strategies, challenges, rewards, levels and continuous feedback (Kohlhaas et al, 2018). SGs are software with learning characteristics that alternated between learning tasks and playful parts (Tolks et al., 2018).

"Serious games" began to emerge around 1970. SGs offer benefits such as motivational effect and ease of learning, discovery learning, and socialization (Faria \& Colpani, 2018). The term SG is a characteristic attributed to games that educate, train, and inform. Serious Games can engage and motivate in various activities in people's daily lives through learning and exercises (Sales; CLÍMACO; SALES, 2016). The motivating intention is to make the activities more interesting and fun (Fernandez-Cervantes, 2015). These characteristics allow developing new possibilities for several areas of knowledge, including the medical field (Kohlhaas et al, 2018). SGs then offer a new mechanism for teaching and training, combining digital games with education (SIDHU, 2010).

SGs allow the simulation of routine activities (a clinical case simulation tool), constituting an application with potential for declarative and procedural teaching and knowledge. Serious games are characterized by an innovative approach from which to develop a learning environment (Gorbanev et al, 2018). In the published studies some SGs were cited: MInPOng, Simulink, TDAHApp, Pedagotchi Pescar. MinPong, for example, was used for the rehabilitation process of people affected by problems caused by stroke; ADHD was used for the recovery process of people with degenerative problems; and Pedagotchi was used to assess the knowledge of medical students.

It is important to highlight that the use of serious games requires planning because if the player does not understand the

rules, the objectives of the game, the behavioral consequences, and the reasons for the consequences, those will not succeed (Silva et al., 2011).

The study aims to conduct a systematic review on the use of Serious Games in Medicine, exploring how the method has been used. Some questions were formulated for this Systematic Review (SR), as follows: Q1 - What is the relevance of the insertion of Serious Games in the medical field? Q2 - In which areas of Medicine have Serious Games been used? Q3 - Which characteristics of Serious Games are used in Medicine?

\section{Methodology}

A systematic review is a type of secondary study whose purpose is to survey the state of the art on a subject using criteria to solve a particular research question/problem. The review follows some principles. The conduct of the systematic review followed three steps of the guidelines of Kitchenham (2007): planning, execution and analysis of the results obtained, as shown below. 


\subsection{Planning}

The plannng is an instrument capable of guiding the researcher in conducting the research in a coherent and agile manner. This resource guides the researcher through steps in the construction of the study, defining research questions, database, search string, criteria, language and search period

\subsubsection{Definition of research questions}

Q1 - What is the relevance of the use of SG in the medical field?

Q2 - In which areas of Medicine have SG been used?

Q3 - What are the characteristics of SG used in Medicine?

\subsubsection{Source selection}

The search strings were applied to the IEEE, Scopus, Scielo and Mediline databases.

\subsubsection{Languages}

Articles published in English and Portuguese were considered, as well as books.

\subsubsection{Search String}

Scopus database: Search String - TITLE-ABS-KEY ("development") AND TITLE-ABS-KEY ("serious games") AND TITLE-ABS-KEY (medicine)

IEEE Database: Search String - (("All Metadata": "serious games") AND "All Metadata":medicine)

Scielo Database: Search String - (medicine) AND ("serious games")

Database Mediline: Search string: Serious AND games, AND medicine, AND development.

\subsection{Restrictions}

Inclusion criteria:

Articles were included following the following criteria:

C1 - Articles must deal with the topic of Serious Games;

C2 - Articles about the use of Serious Games in Medicine;

C3 - Articles within the time frame of 2015 to 2020.

Exclusion criteria:

Articles were excluded following the following criteria:

E1 - Articles on Serious Games in other areas;

E2 - Articles outside the timeframe established from 2015 to 2020;

E2 - Gamification and Medicine;

E3 - Systematic Reviews, considering that we are conducting a primary study.

\subsection{Search period}

Articles published in the period between 01/01/2015 and 11/20/2020 were considered. Chart 1 below shows the number of articles per database: 
Graphic 1 - Return of the databases.

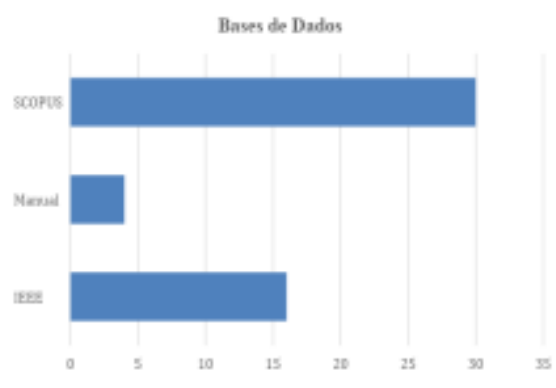

Source: Authors (2021).

From the presented graph it is possible to observe that the largest quantity of articles was extracted from the SCOPUS database, with 30 findings, followed by IEEE with 16 and Manual with 04 articles. They were found with the strings: Scielo (medicine) AND "serious games"), Mediline - Serious AND games, AND medicine, AND development, Scopus - TITLE-ABSKEY ("development") AND TITLE-ABS-KEY ("serious games") AND TITLE-ABS-KEY (medicine) and IEEE (("All Metadata": "serious games") AND "All Metadata":medicine), published between 01/01/2015 and 11/20/2020.

After a thorough analysis of the articles and application of the inclusion and exclusion criteria, 16 papers were selected for the review for summarization and discussion on the use of Serious Games in Medicine. Below I present table 2 with the articles read (ID, Title, Database, Authors, Keywords and Year).

Table 1: Selected Articles for Reading.

\begin{tabular}{|c|c|c|c|c|c|}
\hline ID & Title & Database & Authors & Keywords & Year \\
\hline A8 & $\begin{array}{l}\text { Exploring the Impact of Serious Games } \\
\text { for Cognitive Functions through the } \\
\text { Humphrey } \\
\text { Fellowship Programme }\end{array}$ & SCOPUS & Tan, W.H & $\begin{array}{l}\text { Cognitive; Device; } \\
\text { Medicine; Serious games }\end{array}$ & 2018 \\
\hline A34 & $\begin{array}{l}\text { Biomedical Serious Game System for } \\
\text { Lower Limb Motor Rehabilitation of } \\
\text { Hemiparetic Stroke Patients }\end{array}$ & IEEE & $\begin{array}{lll}\text { F. Noveletto; A. } & \text { V. } \\
\text { Soares; F. L. } & \text { F. } \\
\text { Eichinger; S. } & \text { C. } \\
\text { Domenech; M. } & \text { d. } & \text { S. } \\
\text { Hounsell; P. B. Filho } & \end{array}$ & $\begin{array}{l}\text { Games; Knee; Medical Treatment; } \\
\text { Legged Locomotion; Training; } \\
\text { Muscles; Task Analysis; Stroke; } \\
\text { Serious Games; Lower Limb } \\
\text { Rehabilitation }\end{array}$ & 2020 \\
\hline A31 & $\begin{array}{l}\text { Robotic-assisted serious game for motor } \\
\text { and cognitive post-stroke rehabilitation }\end{array}$ & IEEE & $\begin{array}{l}\text { S. Heins; S. Dehem; V. } \\
\text { Montedoro; B. Dehez; } \\
\text { M. Edwards; G. Stoquart; } \\
\text { F. Rocca; P. H. De } \\
\text { Deken; M. Mancas; T. } \\
\text { Lejeune }\end{array}$ & $\begin{array}{l}\text { Robots; Trajectory; Regulators; } \\
\text { Atmospheric Measurements; Particle } \\
\text { Measurements }\end{array}$ & 2017 \\
\hline A5 & $\begin{array}{l}\text { What can be achieved with motivation- } \\
\text { based teaching of medical students? A } \\
\text { monocentric retrospective audit of } \\
\text { retention among highly motivated } \\
\text { graduates who underwent the learning- } \\
\text { by-doing concept in anesthesiology and } \\
\text { intensive care medicine }\end{array}$ & SCOPUS & $\begin{array}{l}\text { Klincova, M.; Harazim, } \\
\text { H.; Schwarz, D.; } \\
\text { Kosinova, } \quad \text { M.; } \\
\text { Smekalova, O.; Stourac, } \\
\text { P. }\end{array}$ & $\begin{array}{lr}\text { Anesthesiology; } & \text { Intensive Care; } \\
\text { Problem-Based } & \text { Learning; } \\
\text { Specialization; Virtual Patients }\end{array}$ & 2019 \\
\hline A1 & $\begin{array}{l}\text { A secure mHealth application for } \\
\text { attention deficit and hyperactivity } \\
\text { disorder }\end{array}$ & SCOPUS & $\begin{array}{lr}\text { Rodríguez-Perez, } & \text { N.; } \\
\text { Caballero-Gil, } & \text { P.; } \\
\text { Rivero-García, } & \text { A.; } \\
\text { Toledo-Castro, J. } & \\
\end{array}$ & $\begin{array}{l}\text { ADHD; Gamification; Mhealth; } \\
\text { Mobile Application; Security }\end{array}$ & 2019 \\
\hline A14 & $\begin{array}{l}\text { Serious games: Rehabilitation fuzzy } \\
\text { grammar for exercise and therapy } \\
\text { compliance }\end{array}$ & SCOPUS & $\begin{array}{l}\text { Fernandez-Cervantes, } \\
\text { V.; Stroulia, E.; Oliva, } \\
\text { L.E.; Gonzalez, F.; } \\
\text { Castillo, C. }\end{array}$ & & 2016 \\
\hline A13 & $\begin{array}{l}\text { Maximizing the impact of E-Therapy and } \\
\text { Serious Gaming: Time for a paradigm } \\
\text { shift }\end{array}$ & SCOPUS & $\begin{array}{l}\text { Fleming, T.M; Beurs, D } \\
\text { de; Khazaal, Y; Gaggioli, } \\
\text { A; Riva, G; Botella, C; } \\
\text { Baños, R.M; Aschieri, F; } \\
\text { Bavin, L.M; Kleiboer, A; } \\
\text { Merry, S; Lau, H.M; } \\
\text { Riper, H. }\end{array}$ & $\begin{array}{l}\text { CCBT; Computerized Therapy; } \\
\text { Implementation; Serious Games }\end{array}$ & 2016 \\
\hline
\end{tabular}




\begin{tabular}{|c|c|c|c|c|c|}
\hline A32 & $\begin{array}{l}\text { Development of an EMG-Controlled } \\
\text { Serious Game for Rehabilitation }\end{array}$ & IEEE & $\begin{array}{l}\text { M. Ghassemi; K. } \\
\text { Triandafilou; A. Barry; } \\
\text { M. E. Stoykov; E. Roth; } \\
\text { F. A. Mussa-Ivaldi; D. G. } \\
\text { Kamper; R. Ranganathan }\end{array}$ & $\begin{array}{l}\text { Muscles; Electromyography; } \\
\text { Graphical User Interfaces; } \\
\text { Training; Games; Task Analysis; } \\
\text { Medical Treatment }\end{array}$ & 2017 \\
\hline A30 & $\begin{array}{l}\text { Graphical Simulation of Clinical } \\
\text { Scenarios for Medical Training }\end{array}$ & SCOPUS & $\begin{array}{l}\text { Pinto, D; Costa, J; } \\
\text { Nóbrega, R; Silva, H da; } \\
\text { Coelho, A. }\end{array}$ & $\begin{array}{l}\text { Computer } \quad \text { Graphics; } \quad \text { Medical } \\
\text { Simulation; Serious Games }\end{array}$ & 2019 \\
\hline A11 & $\begin{array}{l}\text { Studying practice management via } \\
\text { serious games-which knowledge should } \\
\text { be conveyed? [Praxismanagement } \\
\text { spielerisch lernen-welche Inhalte sollen } \\
\text { unbedingt vermittelt werden?] }\end{array}$ & SCOPUS & $\begin{array}{l}\text { Kohlhaas, A; Leibner, M; } \\
\text { Binder, T; Schütz, J; } \\
\text { Zwierlein, } \\
\text { Steinhäuser, J. }\end{array}$ & $\begin{array}{lrr}\text { E-Learning; } & \text { Economics; } & \text { Practice } \\
\text { Management; } & \text { Serious } & \text { Game; } \\
\text { Simulation Game } & \end{array}$ & 2018 \\
\hline A47 & $\begin{array}{l}\text { Serious Games in Surgical Medical } \\
\text { Education: A Virtual } \\
\text { Emergency Department as a Tool for } \\
\text { Teaching Clinical Reasoning } \\
\text { to Medical Students }\end{array}$ & Manual & $\begin{array}{l}\text { Seung-Hun Chon; } \\
\text { Ferdinand Timmermann; } \\
\text { Thomas Dratsch; Nikolai } \\
\text { Schuelper; Patrick } \\
\text { Plum; Felix Berlth, Rabi } \\
\text { Raj Datta; Christoph } \\
\text { Schramm; Stefan } \\
\text { Haneder; Martin } \\
\text { Richard Späth; Martin } \\
\text { Dübbers; Julia Kleinert; } \\
\text { Tobias Raupach; } \\
\text { Christiane Bruns; Robert } \\
\text { Kleinert1 }\end{array}$ & 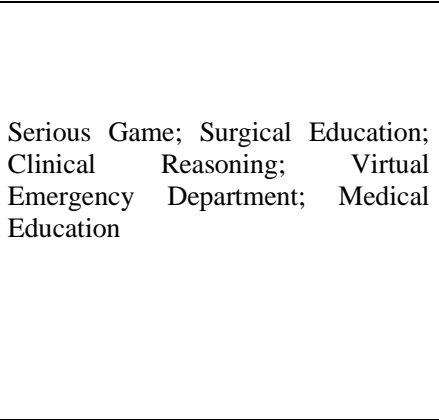 & 2019 \\
\hline A10 & 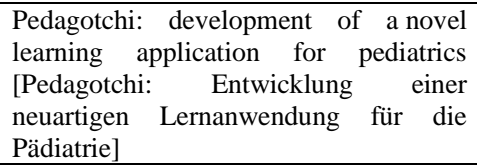 & SCOPUS & Schmidt, R; Grigull, L. & $\begin{array}{l}\text { Case Based Learning; Clinical } \\
\text { Reasoning; Medical Education; } \\
\text { Serious Games }\end{array}$ & 2018 \\
\hline A46 & $\begin{array}{l}\text { Design and Development of Balance } \\
\text { Training Platform and Games for People } \\
\text { with Balance Impairments }\end{array}$ & IEEE & $\begin{array}{l}\text { N. Amritha; Menon M. } \\
\text { Mahima; K. Namith; R. } \\
\text { Unnikrishnan; Mohan } \\
\text { T.Harish; Sankaran Ravi } \\
\text { M.D; Rao R. Bhavani }\end{array}$ & $\begin{array}{l}\text { Balance Impairment; Force Plate; } \\
\text { Balance Training; } \\
\text { Rehabilitation; Shysical } \\
\text { Virtual Reality }\end{array}$ & 2017 \\
\hline A9 & $\begin{array}{l}\text { Validity Evidence for a Serious Game to } \\
\text { Assess Performance on Critical Pediatric } \\
\text { Emergency Medicine Scenarios }\end{array}$ & SCOPUS & $\begin{array}{l}\text { Gerard, J.M; Scalzo, A.J; } \\
\text { Borgman, M.A; Watson, } \\
\text { C.M; Byrnes, C.E; } \\
\text { Chang, T.P; Auerbach, } \\
\text { M; Kessler, D.O; } \\
\text { Feldman, B.L; Payne, } \\
\text { B.S; Nibras, S; Chokshi, } \\
\text { R.K; Lopreiato, J.O. }\end{array}$ & $\begin{array}{l}\text { Assessment; Pediatric Advanced Life } \\
\text { Support; Serious Game; Simulation }\end{array}$ & 2018 \\
\hline A7 & $\begin{array}{l}\text { Herbopolis A mobile serious game to } \\
\text { educate players on herbal medicines }\end{array}$ & SCOPUS & $\begin{array}{l}\text { E, R.W.X; Yap, K.Z; } \\
\text { Yap, K.Y.-L. }\end{array}$ & $\begin{array}{l}\text { Complementary and alternative } \\
\text { medicines; Herb-related knowledge; } \\
\text { Herbal medicines; Herbopolis; } \\
\text { Mobile game; Serious game }\end{array}$ & 2018 \\
\hline A49 & $\begin{array}{l}\text { A Clinical Case Simulation Tool for } \\
\text { Medical Education }\end{array}$ & Manual & $\begin{array}{l}\text { GASPAR S. J; SANTOS } \\
\text { JR; R. M; REIS N. S. Z }\end{array}$ & $\begin{array}{lr}\text { Computer Simulation; } & \text { Gamification; } \\
\text { Competency-Based } & \text { Education; } \\
\text { Clinical Diagnosis; } & \text { Medical } \\
\text { Education } & \\
\end{array}$ & 2016 \\
\hline A50 & $\begin{array}{l}\text { Jogos sérios em ambiente virtual para } \\
\text { ensino-aprendizagem na saúde }\end{array}$ & Manual & $\begin{array}{l}\text { SANTOS C. A; SOUZA- } \\
\text { JUNIOR V. D; LANZA } \\
\text { F. F; LACERDA A. J; } \\
\text { JORGE M. B; } \\
\text { MENDES I. A. C. }\end{array}$ & $\begin{array}{l}\text { Video Games; Simulation Training; } \\
\text { Health Education; Computer Program } \\
\text { Validation }\end{array}$ & 2017 \\
\hline
\end{tabular}

Source: Authors (2021).

Table 1 shows the articles that were selected according to the inclusion and exclusion criteria. The analysis of the selected papers is presented below.

Digital games are increasingly becoming entertainment software used by countless people, regardless of age, culture, or country. The idea of using digital games for learning has made people wonder about the power of these new media as tools for learning. However, it should be noted that the design guidelines for computer games used in educational settings should be no different from those for any educational software. Thus, game design should cover a wide range of skills and provide student support as well as guidance for teachers to plan the use of the game for academic purposes (Zainon \& Zawari, 2013). In this 
sense, digital games emerge as a teaching alternative full of functions that can provide numerous benefits for teaching practice (Santos et al, 2017).

With the advancement of technology, tools have been optimized over time to improve processes (Gomes et al., 2018). Clinical decision making is a complex challenge for physicians and for medical students, how to apply the knowledge they have learned to arrive at a patient's diagnosis is also a challenging learning process (Schmidt \& Grigull, 2018). Serious Games have been used for various educational interventions in health promotion and prevention (Tolks et al., 2018). The following studies present reports on the use of Serious Games in important areas of medicine.

\section{Results and Discussion}

As I read the articles about Serious Games in medicine, I found that the studies reported on their existence, as well as on their importance and use as a tool to enhance the teaching/learning of medicine. Thus, making use of them to strengthen the learning of future physicians, given their multiple resources. This can be proven by the ease with which they engage the student. It must be clear that we are talking about the $\mathrm{Y}$ generation, that is, natives of the network. The gaming environment is common to most of them. By absorbing the points mentioned above, it was clear that the use of Serious Games emerges as a useful mechanism for medical students, since the games offer possibilities of involving their users with disciplines that are more focused on the repetition of specific activities. However, we cannot fail to mention the fact that some areas are not yet contemplated by these tools, such as ophthalmology, dermatology, orthopedics, and traumatology, since they have not been mentioned in the studies read so far. There are numerous possibilities for their non-inclusion.

\subsection{Use of Serious Games in the recovery process of people affected by cognitive problems}

The study by A13 highlights the importance of online programs, apps, and serious games that promise to increase access to treatment and prevention mental health remotely. According to the study, the publicly available self-help program, MoodGYM, attracted approximately 38,000 downloads in a short period of time (14 months). The mental health app Happify was downloaded an average of 300,000 times on Google Play as of December 16, 2015 (Fleming et al, 2016).

Study A13 shows us that there is a significant increase by the search for e-therapy and Serious Games in mental health. However, according to the study, user-centered approaches such as individualization, interventions and exploration of modularized programs are somewhat lacking, as well as a greater emphasis on engagement and utilization of processes such as games, telepresence and engagement measurement (Fleming et al, 2016).

Study A30 reports that SGs have specific purposes since the player uses their knowledge to solve some problem or train a specific task. The application of SG in healthcare can benefit from this method and develop serious games or SG-type systems, which is not only a means of experience and knowledge, but also a means of active learning (Pinto et al, 2018).

It is noticeable that Serious Games are increasingly attracting the interest of the medical profession to keep people engaged in the recovery processes (cognitive or physical). It is possible to observe that the insertion of a SG is of fundamental importance, therefore, if used in the right way, it can provide more playful and less tedious recovery processes. The following studies present answers to questions 01, 02 and 03 of the review (Pinto et al, 2018).

In response to question Q1, article A8 points out that the insertion of Serious Games in Medicine has gained great proportion given that pharmaceutical revenues in North America have exceeded US \$1 trillion globally since 2014 (Q3). The potential of this lucrative business opportunity may attract fund providers and venture capitalists to support research related to Serious Games. According to the study, this trend has motivated interdisciplinary cooperation in the medical sciences and the gaming industry (Hoe, 2018). 
In response to Q2, study A8 further highlights that empirical studies have begun to show evidence that the effects of brain training games, i.e. Serious Games, play a significant role in the recovery process of people with attention deficit disorder (HOE, 2018). Attention deficit hyperactivity disorder (ADHD) is a neurodevelopmental disorder with a basic triad of symptoms: inattention, confusion, and/or hyperactivity (Theodório et al., 2020).

Corroborating with the idea of using Serious Games in the recovery process of people with attention deficit (Q2), the study A1 presents a mobile application, the TDAHApp Interactive, which can be used as a tool to improve the treatment of ADHD, i.e., identify the symptoms to make a pre-diagnosis and inform about ADHD. The proposal was to create a network of people involved in the care of the child, which allows the collection of data by the medical professional that can be visualized and evaluated to schedule possible intervention plans. Thus, one of the main functionalities of the application is the integration of different user profiles in order to share relevant data among them. The main user profiles for collaboration are the following: parents, medical staff, children, and teachers. The idea of the game by attracting people was to help people with attention deficit (Rodriguez-Pérez et al, 2019).

The ADHD tool presented in the A1 study has an initial questionnaire composed of questions about the patient's attitudes and characteristics, which presents the main criteria used to diagnose ADHD. After data collection, the medical team undertakes the evaluation to provide an accurate diagnosis. If the diagnosis turns out to be positive, the developers have inserted in the tool three main types of games, which were included in order to help in the correct development of the cognitive activities of children can be used to enrich the teaching and learning process (Fernandez-Cervantes, 2015).

\subsection{Use of serious games in the recovery process of people affected by problems due Cerebral Vascular Accident (CVA)}

The study A14 brought us a view that SGs can be used for the rehabilitation work of people with (stroke). In this sense, in A35 it was possible to see that Serious Games also have a strong contribution in the rehabilitation process of people affected by Cerebral Vascular Accident -CVA (Noveletto et al, 2020).

Study A31 addresses important points of questions Q1 and Q2 of the review, in which it was possible to observe the importance of the insertion of a serious game for the rehabilitation process of stroke (Cerebral Vascular Accident - CVA) patients. The proposed SG called mimPong was inspired by the classic video game Pong (Q3), in which the objective was to control a tennis racket to hit a ball (Noveletto et al, 2020).

The visual questions in the game were simple and directed the patient to hit the ball. When no force was applied, the rackets remained stationary at the bottom of the screen. To facilitate the visualization of the graphs and analysis of the data of maximum force, force maintenance, response time, an interface screen was developed (Noveletto et al, 2020).

The game data could be stored in a text document, including ball center position, racket center position, force value, game settings and game score (Noveletto et al, 2020).

The results showed that with the insertion of the SG the treatment was satisfactory for the patients. The mimPong scoring system allowed both the therapist and the patient to follow the evolution of the treatment in a simpler way. In answer to question Q1, the study proved that mimPong not only worked as a motivational aspect for the patient, but also as an evaluation index for the therapist. Thus, its scoring system is a positive contribution (Noveletto et al, 2020).

Article A31 is another study that highlights the importance of the use of Serious Games in the rehabilitation of people affected by a stroke. Besides mentioning the importance of Serious Games in the rehabilitation process, the study emphasizes that Serious Games are not only for entertainment or fun (Heins et al, 2017). The main goal of a SG is the improvement of motor and/or cognitive function considering that the serious game allows the continuous adaptation of the exercise difficulty according to the patients' abilities (Heins et al, 2017). 
According to the study A31, in addition to facilitating learning, Serious Games can also be highly engaging and motivating, facilitating patient involvement in the rehabilitation process (Heins et al, 2017).

The article further highlights that studies in the literature have already shown several potential benefits of Serious Games in stroke rehabilitation (Q1), such as the use of a video game designed for hemoglobin rehabilitation was positively accepted by the patient and showed improved performance. In response to Q3, the main objective of the study was to develop the robotassisted serious game (ROBiGAME) to rehabilitate cognitive and motor impairments after a stroke (Heins et al, 2017).

The structure of the game allowed to evaluate the patient's performance and adapt the level of play according to their specificity. The game was considered fun due to the large number of targets, the variety of challenges, and distracting elements. According to the authors, the cognitive aid strategy and the conditions for triggering motor assistance need to be reviewed. The game provided feedback on the patient's performance during the game (Heins et al, 2017).

Continuing the discussion about the importance of SG in the rehabilitation process, study A32 developed a platform called Simulink as based on electromagnetic (EMG) signals in which its goal was the training of multimuscular activation patterns in stroke (Cerebral Vascular Accident - CVA) patients with neurological damage. The goal of the tool was the process of reoccupying the moments of the hand. Through the platform, three important Serious Games were created: The Target, Image Revelation, and Maze (Ghassemi et al, 2019).

Study A32 indicated the characteristics of the developed SGs: The Target - its main objective was the exercise of moving the cursor to a specified block once the user successfully moves the cursor to the target block and keeps the cursor "stopped" for a period, the block turns yellow, alerting the user to continue. Once the recommended block is reached, the block light turns green.

Image Reveal - for this exercise, once the cursor meets the stopping criteria, the block disappears to reveal part of an image below. By moving to different blocks, the user can reveal more of the image of free choice (Ghassemi et al, 2019). It would be like a kind of puzzle or finding out pieces until it shows the result (the image).

Maze exercise - the user must control the cursor to find a path. The cursor cannot move in front of the walls of the maze, from which the player must create his patterns to control the cursor around the walls. Feedback of the chosen path is provided by indicating the current location of the cursor with a red diamond and the previously occupied tiles with yellow diamonds, thus decreasing the difficulty and keeping the player engaged to complete the treatment session (Ghassemi et al, 2019).

Study A14 presents SG "Fishing," which uses the idea of "fishing in a quiet lake" to engage and motivate people in a rehabilitation regimen (Q2 and Q3) for elbows. SG was used with the aid of the Xbox Kinect console to monitor the physical therapy rehabilitation process, i.e., the console was used as a mere instrument for the installation of the Serious Games, as the Kinect is a sensor capable of accurately observing the player's movements (Fernandez-Cervantes, 2015). The Serious Games used in this study had as main objective to simulate the proper postures that the patient would have to follow in the rehabilitation process; the player following this step by step would achieve his full recovery.

\subsection{Using Serious Games in Medical Education}

In A49 we have that even though they are potentially inclined to learn, humans need incentives to do so effectively. Today, teachers must be the facilitators of the teaching process. In this sense, students are acquiring skills and professional capacity (Gaspar; SANTOS JÚNIOR; REIS, 2016). However, the training of the medical student requires the exhaustive repetition of specific activities, the control of behaviors, and the adaptation to the learning moment. The virtual environment can simulate the challenges of clinical practice and at the same time takes into account personal experience, which can stimulate students' interest and provides other more recent high-quality theoretical content (Gaspar et al., 2016). 
The central idea of the study was the development of an application (Case Simulation) for the storage of clinical cases providing technical support for courses and in the classroom, managing content, evaluation and student performance. In the tool, the teacher had the role of teaching-learning process conductor, collecting and documenting clinical cases in the form of text, sound and images, from the real scenarios and registering them in the virtual environment for later use as a tool to support health education. The teacher also had to prepare clinical challenges in the virtual environment in the form of questions/answers (quiz) with report tracks, images, graphics, videos and specific theoretical content to support the training (Gaspar et al., 2016).

Study A47 highlights that the availability of serious games that offer a high-fidelity environment in combination with medical training is still somewhat limited. However, Serious Games enable playful daily work practices and are a potential tool for teaching medical procedures through simulations (Chon et al, 2019).

Article A5 shows us that Serious Games have also been used in the area of education in medicine (Q1 and Q2), that is, with the development of serious games by means of the AKUTNE.CZ Multimedia Educational Platform of the Masaryk University Faculty of Medicine (FMMU) for the AIM specialty (Klincova et al, 2019). The central goal of the AKUTNE.CZ Multimedia Educational Portal was to produce elementary traits of physicians dealing with acute patients (algorithmic thinking and correct clinical reasoning). It is motivation-based learning by doing for both students and teachers.

Serious games (A10) combine playful and motivational qualities with didactically prepared content. By simulating and abstracting real events, they allow risk-free exploration of tedious and "boring" tasks and solutions. Serious games can offer medical students a valuable addition to learning the clinical decision-making process (Schmidt \& Grigull, 2018).

Study A5 showed that it was possible to retain the attention of medical undergraduates with motivation-based teaching. The authors' purpose was to show that students are adept at learning by doing, so the development of the algorithm (Q3) itself, as part of the learning by doing process, supports critical thinking and decision making and these are the two main skills that are useful, especially for physicians. The creation of Interactive Multimedia Algorithms (AIM) is extremely demanding, time consuming, and often monitored (Klincova et al, 2019).

The algorithm team met regularly to check progress and workflow according to the schedule. There were three group meetings of the entire AKUTNE.CZ team in a semester to motivate, simulate a creative environment, and provide an openminded discussion forum. 142 undergraduate medical students participated in the study. In view of the study, it can be seen that such a technique was efficient for the learning process, but more research is still needed (Klincova et al, 2019). Serious games have significant advantages such as completing challenges. In this sense also, the acquisition of information becomes easier, as well as the promotion of teamwork, recreation of complex clinical situations, and feedback to learn from mistakes (Pinto et al, 2018).

Still on the subject of using SG for teaching, study A30 shows the training of healthcare professionals through graphical simulations using serious games. The goal was to develop a prototype for simulating hospital environments and medical training, recreating several clinical situations: in-hospital, pre-hospital, and transport environments (Pinto et al, 2018). The platform developed was flexible and sought to meet what had been previously mentioned focusing mainly on emergency or critical cases that needed team training.

Continuing with the discussion of the use of Serious Games in the field of medical education, study A47 aimed to test the effect of a SG simulating an emergency room ("EMERGE"). The SG simulated a free navigation through a virtual emergency department in which a digital guide helped the student to handle the interface and treat patients. Upon starting the simulation, students would obtain information about the incoming patient from emergency cases, they would send the patients to an examination room, obtaining the medical history and thus requesting diagnostic tests from the patient, as well as establishing a diagnosis by taking the patient's medical history (Chon et al, 2019). The SG was developed at the Göttingen Medical School in partnership with the University Medical Center Hamburg-Eppendorf, ensuring the educational quality of the program. 
In A10 the goal of the serious game Pedagotchi was to provide students with case-based training. At the start of the SG the user was offered an intuitive menu with four categories: the treatment room, a help forum, the story and a reward screen. The focus was on the treatment room. The scenario was based on real cases. For each disease case there is a short information text about a specific disease. At the end of the trainings a forum called in-game was held in conjunction with a seminar, which offered several opportunities to exchange information and a way to communicate among peers (Schmidt \& Grigull, 2018).

In A9 the main goal was the development of a Serious Game about pediatric emergency (PediatricSim), which aimed to teach and assess medical students in essential pediatric settings such as: allergic reactions, bronchiolitis, diabetic ketoacidosis, respiratory failure, and seizures. The SG allows the student to assume the role of leader and guides them in the management of patients through the selection of assessment and treatment options. Participants used the SG independently in a supervised setting (Gerard et al, 2018).

For the validation of the PedriatricSim, Scores were used to assess students' knowledge of pediatric emergency management (PEM), i.e., the PediatricSim had scoring rubrics that were developed by a team of 11 experts in the field of pediatric emergency and pediatric intensive care medicine. Importantly, the use of the SG followed the recommendations of the American Heart Association (AHA) and other official guidelines (Gerard et al, 2018).

Given the studies cited, it was possible to identify that investing in this process is fundamental so that it can count on the collaboration of researchers, teachers and students in the process of teaching innovation in health care (Santos et al, 2017).

\section{Final Considerations}

The SR brought us answers about the relevance of Serious Games in the medical field. From the readings it was possible to observe that Serious Games present a great potential for the field, because the method has as a characteristic the focus on learning and recovery of patients. With the help of SG it is possible that approaches are made by doctors and medical students in the search for approaching hard-to-reach groups and enables immersion, narrative and interaction with feedback among the subjects involved. According to the studies, SG are used mainly in the areas of recovery of people with stroke sequelae and with cognitive problems, besides being used in the process of teaching Medicine.

It was also possible to observe that Serious Games are part of the culture (Xuan et al., 2018). It is not a new technology, but has always been closely linked to learning. Various factors influencing the development of Serious Games have led to a diverse, multidisciplinary and interdisciplinary field of research and application.

According to the studies surveyed, it was evidenced that if used correctly, SG can assist not only physicians (graduates), but also future graduates, given that SG have also been used as motivating and engaging tools for medical students. The SGs were used in clinical simulation platforms, favoring students with the tactic of learning by doing.

For future work, it can be highlighted that it is possible to carry out new work regarding the use of SGs in a collaborative and remote way to even remedy the problems related to the distance needs generated by COVID-19 (use in telemedicine, environments collaborative virtual environments).In summary, we can understand that the subject of Serious Games is a very broad and promising field of research in the medical field that still needs to be further explored.

\section{References}

Chon, S. et al. Serious Games in Surgical Medical Education: a Virtual Emergency Department as a Tool for Teaching Clinical Reasoning to Medical Students. JMIR Serious Games, 07(1).http://games.jmir.org/2019/1/e13028/.

Faria, M. J. de, \& Colpani, R. Avaliação Técnica e Pedagógica do Jogo Sério “Joy e as Letrinhas”. Renote, 16(1). https://doi.org/10.22456/1679-1916.85877.

Fernandez-Cervantes, V. et al.Serious Games: Rehabilitation Fuzzy Grammar for Exercise and Therapy Compliance. Games Entertainment Media Conference (GEM), Toronto, 2015. Anais... https://ieeexplore.ieee.org/document/7377229. 
Fleming, T. M. et al.Maximizing the impact of e-therapy and serious Gaming: time for a Paradigm shift. Frontiers in Psichiatry, Switzerland, 7(65). https://pubmed.ncbi.nlm.nih.gov/27148094.

Gaspar, J. S., Santos Júnior, M. R., Reis, Z. S. N. A Clinical Case Simulation Tool for Medical Education. International Conference on Information Technology in Bio- and Medical Informatics, 2016. Anais... https://10.1007/978-3-319-43949-5_10.

Gerard, J. M. et al.Validity Evidence for a Serious Game to Assess Performance on Critical Pediatric Emergency Medicine Scenarios. Simulation in Healthcare: The Journal of the Society for Simulation in Healthcare, https://journals.lww.com/simulationinhealthcare/Fulltext/2018/06000/Validity_Evidence_for_a_Serious_Game_to_Assess.5.aspx.

Ghassemi, M. et al.Development of an EMG-controlled Serious Game for Rehabilitation. Transactions on Neural Systems and Rehabilitation Engineering, Gainesville, 27(2). https://doi.org/10.1109/tnsre.2019.2894102.

Gomes, T. C. F., Oliveira, E. C., Oliveira, L. C. Serious Game para Aprendizagem de Cirurgias com Óculos de Realidade Virtual. Congresso Brasileiro de Eletromiografia e Cinesiologia / Simpósio de Engenharia Biomédica, 5 / 10, 2018. Anais... https://www.researchgate.net/publication/322646502.

Gorbanev, I. et al. A systematic review of serious games in medical education: quality of evidence and pedagogical strategy. Medical Education Online, [s/l], 23. https://doi.org/10.1080/10872981.2018.1438718.

Heins, S. et al.Robotic-assisted serious game for motor and cognitive post-stroke rehabilitation. International Conference on Serious Games and Applications for Health (SeGAH), 5, Perth, 2017. Anais... https://ieeexplore.ieee.org/document/7939262/.

Hoe, T. W. Exploring the Impact of Serious Games for Cognitive Functions through the Humphrey Fellowship Programme. Malaysia Journal of Medical Sciences, Pulau Pinang, 25(3). http://journal.usm.my/journal/01MJMS25032018_ED.pdf.

Kitchenham, B. Charters, S. "Guidelines for performing Systematic Literature Reviews in Software Engineering," Keele University and Durham University Joint Report EBSE 2007-001, 2007. https://www.elsevier.com/_data/promis_misc/525444systematicreviewsguide.pdf

Klincova, M. et al. What Can Be Achieved With Motivation-Based Teaching of Medical Students? A Monocentric Retrospective Audit of Retention Among Highly Motivated Graduates Who Underwent the Learning-by-Doing Concept in Anesthesiology and Intensive Care Medicine. JMIR Serious Games, Toronto, 7(2). https://games.jmir.org/2019/2/e10155/.

Kohlhaas, A. et al. Praxismanagement spielerisch lernen - welche Inhalte sollen unbedingt vermittelt werden? Z Allg Med, 94(1). 10.3238/zfa.2018.0029-0034.

Noveletto, F. et al. Biomedical Serious Game System for Lower Limb Motor Rehabilitation of Hemiparetic Stroke Patients. Transactions on Neural Systems and Rehabilitation Engineering, Gainesville, 28(6) https://ieeexplore.ieee.org/document/9069313.

Pinto, D. et al.Graphical Simulation of Clinical Scenarios for Medical Training. International Conference on Graphics and Interaction (ICGI), Lisboa, 2018. Anais... https://ieeexplore.ieee.org/abstract/document/8602866/.

Rocha, R. V. da, Bittencourt, I. I., Isotani, S. Análise, Projeto, Desenvolvimento e Avaliação de Jogos Sérios e Afins: uma revisão de desafios e oportunidades. Simpósio Brasileiro de Informática na Educação, 26, 2015. Anais... https://www.br-ie.org/pub/index.php/sbie/article/view/5342.

Rodriguez-Pérez, N. et al.A secure mHealth application for attention deficit and hyperactivity disorder. Expert Systems, 37(1). https://doi.org/10.1111/exsy.12431. Acesso em: 29 set. 2020.

Sales, A. B., Clímaco, G. S., Sales, M. B. Jogos Sérios em Interação Humano-Computador: uma revisão Sistemática de Literatura. Renote, 14(1) https://seer.ufrgs.br/renote/article/view/67384.

Santos, C. A. et al.Jogos sérios em ambiente virtual para ensino-aprendizagem na saúde. Rev Rene, 18(5) http://www.periodicos.ufc.br/rene/article/view/30851.

Schmidt, R., \&Grigull, L. (2018). Pedagotchi: Entwicklung einer neuartigen Lernanwendung für die Pädiatrie. Monatsschrift Kinderheilkunde, 166 https://link.springer.com/article/10.1007\%2Fs00112-017-0253-9.

Sidhu, M. S. Technology-assisted problem solving for engineering education: interactive multimedia applications. Hershey: Engineering Science Reference, 2010 .

Silva, I. K. de O., \& Morais, M. J. O. (2011) Desenvolvimento de jogos educacionais no apoio do processo de ensino-aprendizagem no ensino fundamental. Holos, Natal, v5 (2011). http://www2.ifrn.edu.br/ojs/index.php/HOLOS/article/view/705.

Silva, T. G., Müller, F. M., \& Bernardi, G. (2011). Panorama do Ensino de Engenharia de Software em Cursos de Graduação Focado em Teste de Software: uma Proposta de Aprendizagem Baseada em Jogos. Renote, 9(2) (2011). https://seer.ufrgs.br/renote/article/view/25115/14610.

Theodório, D. P., Silva, A. P. da, \& Scardovelli, T. A. (2020). Jogos sérios brasileiros para auxílio do diagnóstico e tratamento de TDAH: revisão integrativa. Interfaces da Educação, aranaíba, 11(32) https://periodicosonline.uems.br/index.php/interfaces/article/view/4298.

Tolks, D., Dadaczynsk, K., Horstman, D. Einführung in die Vergangenheit, Gegenwart und Zukunft von Serious Games (for Health). Prävention und Gesundheitsförderung, 13. https://doi.org/10.1007/s11553-018-0667-9.

Xuan, R. W., Zhen, K. E., \& Yap, K. Y. Herbopolis A mobile serious game to educate players on herbal medicines. Complementary Therapies in Medicine, 39. https://linkinghub.elsevier.com/retrieve/pii/S0965229918302255.

Zainon, W. M. N. W., \& Zawari, A. Exploring The Use of Digital Games for Teaching and Learning. International Conference on Computer Graphics, Visualization, Computer Vision and Game Technology, 2013. Anais... 10.2991/visio-13.2014.2. 